\title{
Criminal Accountability of Political Parties in Achieving Fair Election in Indonesia
}

\author{
M Harun ${ }^{1}$,Nyoman Serikat Putra Jaya ${ }^{2}$, RB Sularto ${ }^{3}$ \\ \{harundosen@gmail.com ${ }^{1}$, putrajaya1948@yahoo.co.id ${ }^{2}$, sulartob@gmail.com ${ }^{3}$ \} \\ ${ }^{1,2,3}$ Diponegoro University, Semarang, Indonesia
}

\begin{abstract}
Article 3 Paragraph 1 of Law Number 2 the Year 2008, jo Law Number 2 the Year 2011 on Political Parties, states that Political Parties must be registered to the Ministry to become legal entities. The state legally recognizes political parties that are already legal entities then have rights and obligations as legal subjects. The consequences of the existence of rights and obligations protected by the state make the position of Political Parties can be accounted for by law. Political parties are never held accountable in connection with violations committed by legislative candidates who commit an electoral crime, since the law does not regulate the accountability of political parties against perpetrators of crimes perpetrated by legislative candidates. A regulation that regulates the accountability of a political party to a criminal act committed by a legislative candidate is considered liable in a corporate crime - related to the formulation of the "Sanctions Provision" in Law Number 2 Year 2008, jo Law Number 2 Year 2011 on Political Parties, in which regulate the subject of law (person / person) and political party, corporation (rechtpersoon). Found the problem/ legal problem (legal gap) in the formulation, as follows: a. It is not asserted that a political parties, a corporation as a subject of a crime (which should be contained in the "General Provisions"); b. The determination of sanctions only in the form of administrative and criminal sanctions, especially for criminal sanctions is not accountable to political parties; c. The formulation of its sanctions is cumulative, it should also be considered the formulation of alternative sanctions; d. Formulation of imprisonment for corporation; Should be described in detail about the subject of a criminal offense that must be held accountable because "corporation" cannot be imprisoned, which can be imprisoned is the subject of a criminal act of "people"; e. Not formulated on the determination of when a corporation, a political parties, can be accounted for; f. Not formulated when the board of corporations, political parties can be accounted for; g. Not formulating justification and excuses for corporations, political parties; h. No formulation of penal code/ guidelines for corporations, political parties. It is important to conduct research on the criminal liability of political parties in realizing the fairer elections in Indonesia, with the following issues: How is the formulation policy of criminal responsibility of political parties today? (1) How is the application of corporate criminal liability theory to the legal subject of political parties? (2) How is the formulation of the criminal responsibility of political parties in realizing the fairer elections in Indonesia in the future?
\end{abstract}

Keyword:criminal accountability, political parties, election, fair

\section{Introduction}

Criminal law formulation policy cannot be separated from legal politics. According to Bellefroid, it is interpreted as part of the science of law which examines the changes of applicable law, which must be done to meet the new demands of community life (de rechtspolitiek onderzoekt, welke veranderingen in het bestaande recht moeten worden 
gebracht Om an de nieuwe eisen van het maatschappelijk leven te voldoen) [1]. Citing the opinion of Bellefroid, Utrecht [2] argues that legal politics creates an ius constituendum that should replace ius constitutum and endeavor this constituendum later on as a new ius constitutum.

Bellefroid argued that legal politics that examines the changes in law need to meet the new demands of community life. In this case, legal politics is a part of the jurisprudence that discusses the change of applicable law (ius constitutum) into the law that should (ius constituendum) meet the changing lives of the people. The legal politics of criminal law is a policy of criminal law, according to Soedarto: "to elect to achieve the best results of criminal legislation in the sense of fulfilling the requirements of justice and efficiency"[3] and "Criminal offenses in accordance with circumstances and situations at a time and for future periods "[4]. Basically the politics of criminal law is an attempt to formulate a better law in the context of more effective crime prevention.

Based on this background, it is very important to conduct a research on the criminal responsibility of political parties in realizing a fairer election in Indonesia, in the form of reformulation.

\section{Methodology}

The type of data in this study is qualitative data consisting of primary data and secondary data, in which the two are complementary. Sources of research are in the form of primary legal materials and secondary legal materials. Primary legal material is a legal material that is authoritative, which means having authority, which consists of: legislation, official records or treatises in the making of legislation and judgment decisions. Secondary materials are all legal publications that are not official documents. Legal publications include textbooks, legal dictionaries, legal journals, and comments on court decisions [5].

The documents to be studied as a source of data in legal research are directly related to document studies [6], as follows: 1. Primary legal materials: legislation directly related to the Political Party and the General Election; 2. Secondary legal materials include literature books, archives, personal collections, dissertations, theses or research reports, articles, papers, mass media and autobiographies.

\section{Findings}

As an organization, a political party is a corporation or legal person having different status and arrangements with other juristic person [7]. The status of a legal entity, whether as a private association or specifically as a partial legal order, is granted by the law [8]. Political parties exist legally at the time of receiving status as a legal entity either because of the way of manufacture or after through certain legal procedures. At the time of becoming a legal entity, a political party may act through its organs as a legal person. Political parties here have rights and obligations that are different from the rights and obligations of each member [9].

Law Number 2 Year 2008 Article 3, paragraph 1, jo Law Number 2 Year 2011 on Political Parties, stated that Political Parties must be registered to the Ministry to become a legal entity. The ministry in question is the Ministry of Justice and Human Rights. Political parties that are already legal entities are legally recognized by the state then have rights and obligations as legal subjects. The consequences of the existence of rights and obligations protected by the state make the position of political parties can be accounted for by law. 
Historically, Eli Lederman declared that criminal accountability of legal bodies has been an issue on the legal agenda since the mid-nineteenth century, when the corporations began to play a role in social and economic life in the wake of the urbanization process and the industrial revolution [10]. At that time, on the one hand, corporations play a very important role in people's lives. However, on the other hand, corporate activities can have a negative impact on people's lives, in order to achieve their objectives, the activities of corporations tend to deviate even juridically has been a crime. Therefore, then in the next development there is a shift in the view that the corporation is also a subject of crime in addition to natural man. This means that the denial of corporation punishment based on the doctrine of the universitas delinquere non potest has undergone change by accepting the concept of functional performers. The subsequent development of corporate acceptance as the subject of this criminal offense is not limited to criminal offenses under absolute liability offenses but also to criminal offenses of criminal intent. And at the same time there is the development of the principle of vicarious liability towards the principle of direct liability. The development of corporate criminal liability also ultimately penetrates into various types of criminal acts. Some countries even have included corporations as subjects of criminal offenses in the general section of criminal law, which means that corporations can be accountable for almost all types of criminal offenses [11].

Political parties are never held accountable in connection with violations committed by legislative candidates who commit an electoral crime, because the law does not regulate the accountability of political parties against perpetrators of crimes perpetrated by legislative candidates. A regulation that regulates the accountability of a political party for a criminal act committed by a legislative candidate is considered as liable in a corporate crime.

The application of corporation criminal accountability theory to the legal subject of political parties can be reviewed as follows:

\subsection{Identification Theory or Direct Liability Doctrine}

This doctrine is used as justification for corporate criminal liability even if the corporation is not something that can stand on its own. According to this doctrine, a corporation is judged to have committed a criminal offense directly through a "senior officer" and identified as an act of the corporation itself. Thus, the act of "senior officer" will be viewed as a corporation act.

In this theory that a corporation may be liable to criminal liability, the person committing the offense must be identified first. New criminal liability can be strictly imposed on the corporation if the criminal act is committed by the person who is the "directing mind" of the corporation. The same thing is also expressed by Richard Card, which states that: "the acts and the state of mind of the person are the acts and state of mind of the corporation" (acts or will of the director is the action and will of a corporation [12].

Referring to the theory, it can be identified for structural parties administrators when committing criminal acts in the interests of their political parties, it can be used as justification reasons to account for political parties as legal entities (as corporations). An example of a criminal offense involving political parties officials at the national level and has been criminally charged, is the Democratic Parties (Partai Demokrat), The Prosperous Justice Parties (Partai Keadilan Sejahtera). Both parties are directly linked to criminal acts committed by party leaders at the national level. But only the subject of the law of a person is being convicted, whereas the legal subject of his political parties (legal entity, as corporation) is not criminalized. 


\subsection{Strict Liability or Absolute Liability}

This doctrine is also called faultless accountability or called no-fault liability or liability without fault. Criminal liability is sought without the need to prove the offense of a criminal offender [12].

According to Curzon as quoted by Muladi and Barda Nawawi Arief, the existence of strict liability doctrine is based on the following reasons [13]: a. It is essential to ensure compliance with certain important rules necessary for the welfare of the people; b. Proof of errors (mens rea) will be very difficult for violations related to the welfare of society (in this case one of them is a corporate crime); c. The high level of "social hazard" is caused by the deeds concerned.

Referring to the theory and the reasons for its underlying principle, it is acceptable that the impact of criminal acts committed by political party officials such as political corruption in Indonesia has a social danger.

\subsection{Vicarious Liability Doctrine}

This doctrine is based on the principle of "employment principle" that the employer is the primary responsibility of the actions of his workers or employees. Thus, in this doctrine is seen the principle of "the servant's act is the master act in law" or also known as the principle that reads "the company is liable for the wrongful acts of all its employees"[14].

Hamzah Hatrik quotes Black's opinion on this vicarious liability, namely indirect legal responsibility, for example, the liability of an employer for an employee, or principal for tire contracts of an agent. Hatrik also quotes Roeslan Saleh that in general a person is responsible for his own actions. But for the actions of others in this matter the rule of law determines whowho is considered responsible as a maker [15]

On the other hand, the vicarious liability doctrine is often interpreted as a substitutional liability (the legal liability of one person for the wrongful acts of another) (Hamzah Hatrik, 1996). Basically, this theory or doctrine is derived from civil law applied to criminal law. Vicarious Liability usually applies in civil law of the law of torts based on superior doctrine of respondent.

Referring to the above-mentioned theory, it can be identified that the chairman/ chairman of a political party structurally at each level can be held accountable for a criminal act committed by the undertaker under it as well as his/ her political party/ activist.

In general, the phenomena of legislation in Indonesia, corporations or legal entities can only be accounted for in the criminal law by the parameters (1) unlawful acts committed by persons in a working relationship or other relationship with legal entities/ corporations and (2) unlawful acts It is done in the environment/ atmosphere of legal entity/ corporation seen from the articles of association of the legal entity/ corporation [16].

Responsible corporations in criminal law can be debated on: (1) the conceptual level and (2) the pragmatic level. At the level of concept in relation to the existence of a principle in the criminal law which requires that for the existence of a crime in that person there must be an error (nulla poena sine culpa, kaine straf ohne schuld or actus non facit reum nisi mens sit rea). Here will cause difficulties in accounting for and convicting corporations in the absence of an inner attitude or element of mens rea to the corporation. Besides, the difficulty is also in determining the penalty chosen for the corporation, since criminal sanctions on criminal legislation are designed to be imposed on natural persons or human beings. At the level/ degree of pragmatic there is skepticism about the effectiveness of the criminal liability corporation with respect to the issue of whether the right corporation becomes a target for 
accountability in criminal law and also whether corporate accountability in criminal law to divert the attention of the criminal responsibility of the perpetrators of criminal acts [16].

In the various criminal laws mentioned above and in the draft of criminal law book, corporations are not limited to only those in the form of companies. The meaning of corporations under Indonesian law is a collection of organized persons and/ or assets, whether legal entities or non-legal entities. Thus the limits of the corporation are very wide. Because of the very breadth of the definition, the determination of something is a corporation or not a corporation becomes very difficult. The theoretical issue that arises in relation to the conviction of corporations is what teaches to justify corporations convicted of corporate crime? The teaching used should be able to answer about what elements should be fulfilled and can be proven by the public prosecutor so that the corporation can be convicted as the perpetrator of crime [17].

The research conducted by Mohd Din [18] indicates that the political parties has never been held accountable for violations committed by legislative candidates conducting an election offense, since the law does not regulate the political parties accountability to the perpetrators of crimes perpetrated by candidates for legislative members. A regulation that regulates the political party accountability for crimes committed by legislative candidates is considered as accountable in a corporate crime. In addition, the political parties should have political education to its members and give strict sanctions to members of political parties who commit disgraceful acts.

The published of Supreme Court Regulation Number 13 of 2016 on Corrective Crime Handling Procedures by Corporations, which identifies both corporate and deliberate misconduct. First, if the occurrence of the crime provides benefits or benefits or for the benefit of the corporation. Secondly, if the corporation allows a crime to occur. Third, if the corporation does not take the necessary steps to prevent the occurrence of criminal acts, including to prevent greater impact after the crime occurs. Therefore, it is necessary to take different steps to improve this condition. By pursuing the flow of thought in corporate crime, political parties should also be charged with corruption if the political party administrators or cadres are corrupt on the orders or the knowledge of political parties and the proceeds of corruption are used for the benefit of political parties [19].

Formulation of sanction determination as stipulated in Law Number 2 Year 2008, jo Law Number 2 Year 2011 on Political Parties in chapter XIX Sanctions, in article 47 in the form of administrative sanctions, namely: rejection of registration of political parties as legal entities by the Ministry (paragraph 1); reprimand by the government (paragraph 2); termination of the State Budget/ revenue and expenditure budget until the report is received by the government in the fiscal year concerned (paragraph 3); a reprimand by the Election Commission (paragraph 4); administrative sanctions established by bodies/ institutions charged with maintaining the honor and dignity of political parties and their members (paragraph 5). In article 48 administrative sanctions, namely: a freeze on stewardship by the district court (paragraph 1); the temporary freezing of the relevant political parties shall be in accordance with its level by the district court no later than 1 (one year) (paragraph 2); dissolved by the decision of the Constitutional Court (paragraph 3); the member of the political parties concerned shall be punished with a maximum imprisonment of 2 (two) years and a fine of 2 (two) times the amount of funds received (paragraph 4); the member of the political parties concerned shall be punished with a maximum imprisonment of 1 (one) year and a fine of 2 (two) times the amount of funds received (paragraph 5); the temporary freezing of the management of the relevant political parties at its level by the district court and its assets and shares seized for the state (paragraph 6); the dissolution of political parties by the 
Constitutional Court (paragraph 7). In article 49: every person or company and/ or business entity ...... is criminalized with a maximum imprisonment of 6 (six) months and a fine of 2 (two) times the amount of funds donated (paragraph 1); the administrators of a political parties ... shall be punished with a maximum imprisonment of 1 (one) year and a fine of 2 (two) times the amount of funds received (paragraph 2). Furthermore, in article 50, namely: the administrators of political parties ...... prosecuted under Law Number 27 of 1999 ..... and his political parties may be dissolved.

Reviewing the formulation of sanctions in article 47, article 48, Article 49 and article 50 of Law Number 2 Year 2008, in conjunction with Law Number 2 Year 2011 on Political Parties, found that the types of sanctions in the form of administrative sanctions and criminal sanctions. For criminal sanctions have not regulated the criminal acts of corruption committed by the administrators of political parties that have implications for the criminal responsibility of political parties. Still limited to criminal liability based on legal subjects of people, has not regulated criminal responsibility based on legal subject of political parties.

Including political parties are never held accountable in connection with violations committed by legislative candidates who commit electoral crimes (up to 2014 election), because the law does not regulate the accountability of political parties against perpetrators of criminal acts perpetrated by legislative candidates. A regulation that regulates the accountability of a political party to a criminal act committed by a legislative candidate is considered as liable in a corporate crime.

Related to the formulation of the "Sanctions Provision" in Law Number 2 Year 2008, jo Law Number 2 Year 2011 on Political Parties, in which regulate the subject of law (person/ person) and political parties, corporation (rechtpersoon). Found the problem/ legal problem (legal gap) in the formulation, as follows: a. It is not asserted that a political parties, a corporation as a subject of a crime (which should be contained in the "General Provisions"); $b$. The determination of sanctions is only in the form of administrative and criminal sanctions, especially for criminal sanctions not accountable to political parties; c. The formulation of its sanctions is cumulative, it should also be considered the formulation of alternative sanctions; d. Formulation of imprisonment for corporation; should be described in detail about the subject of a criminal offense that must be held accountable because "corporation" cannot be imprisoned, which can be imprisoned is the subject of a criminal act of "people"; e. Not formulated on the determination of when a corporation, a political parties, can be accounted for; f. Not formulated when the board of corporations, political parties can be accounted for; $g$. Not formulating justification and excuses for corporations, political parties; h. No formulation of penal code/ guidelines for corporations, political parties.

Observing and reviewing the formulation of the "sanctions provisions" described in Law Number 2 Year 2008, jo Law Number 2 Year 2011 on Political Parties, it is very important how to formulate policy on the criminal responsibility of political parties in realizing the election in a more just Indonesia in the future. Placing the legal subject of a political party to be criminally accountable, other than the subject of criminal law in the form of a person who has been regulated in the Political Parties Law. To bridge the legal gap in its formulation, it needs to be regulated and confirmed: a. Political parties, corporations as subjects of criminal offenses contained in "General Provisions"; b. Criminal sanctions other than addressed to legal subjects in the form of persons, also against legal subjects in the form of political parties, corporations; c. Besides the formulation of sanctions is cumulative, it is also necessary to set alternative sanctions; d. Formulation of imprisonment for corporation; should be described in detail about the subject of a criminal offense that must be held accountable because "corporation" cannot be imprisoned, which can be imprisoned is the subject of a criminal act 
of "people"; e. It is necessary to regulate the determination of when a corporation, a political parties, can be accounted for; f. Need to be formulated when the board of corporations, political parties can be accounted for; g. It is necessary to formulate justifications and excuses for corporations, political parties; $h$. The formulation of penal rules/ guidelines for corporations, political parties should be formulated.

\section{Conclusion}

The study of the criminal accountability of political parties in achieving fair election in Indonesia can be summarized as follows:

1. Law Number 2 Year 2008 Article 3 paragraph 1, jo Law Number 2 of 2011 on Political Parties, stated that Political Parties must be registered to the Ministry to become a legal entity. The ministry in question is the Ministry of Justice and Human Rights. Political parties that are already legal entities are legally recognized by the state then have rights and obligations as legal subjects. The consequences of the existence of rights and obligations protected by the state make the position of Political Parties accountable legally;

2. Applying the theory of corporate criminal liability to the legal subject of political parties, can be reviewed as follows: a. Identification Theory or Direct Liability Doctrine; b. Strict Liability or Absolute Liability; and c. Vicarious Liability Doctrine;

3. It is very important how to formulate policies on the criminal accountability of political parties in realizing fairer elections in Indonesia in the future. Placing the legal subject of a political party to be criminally accountable, other than the subject of criminal law in the form of a person who has been regulated in the Political Parties Law, to bridge the legal gap in its formulation.

\section{References}

[1] I. F. Sugeng, Bahan Kuliah Politik Hukum. Yogyakarta: Magister Hukum Program Pascasarjana Universitas Gajah Mada, 2004.

[2] E. ; D. M. S. Utrecht, Pengantar dalam Hukum Indonesia. Jakarta: Ichtiar Baru, 1983.

[3] Soedarto, Hukum dan Hukum Pidana. Bandung: Alumni, 1986.

[4] Soedarto, Hukum Pidana dan Perkembangan Masyarakat Kajian terhadap Pembaharuan Hukum Pidana. Bandung: Sinar Baru, 1983.

[5] P. M. Marzuki, Penelitian Hukum. 2010.

[6] S. Hartono, Penelitian Hukum di Indonesia Pada Akhir Abad ke 20, edisi pertama. Bandung: Alumni, 1994.

[7] M. A. Safa'at, Pembubaran Partai Politik (Pengaturan dan Praktik Pembubaran Partai Politik dalam Pergulatan Republik. Jakarta: Raja Grafindo Persada, 2011.

[8] H. Kelsen, General Theory of Law and State, Translated by Andreas Wedberg. New York: Russel \& Russel, 1961.

[9] Wahyu, "Pertanggungjawaban Pidana Partai Politik yang Melakukan Tindak Pidana," Universitas Brawijaya, 2014.

[10] E. Lederman, "Model for Imposing Corporate Criminal Liability: From Adaptation and Imitation Toward Agregation and The Search for Self Identity Buffalo," Crim. Law Rev., vol. 4, p. 641, 2000.

[11] Setiyono, Teori-Teori dan Alur Pikir Penerapan Pertanggungjawaban Pidana Korporasi. Malang: Bayu Media, 2013. 
[12] Kristian, Sistem Pertanggungjawaban Pidana Korporasi (Tinjauan Teoretis dan Perbandingan Hukum di Berbagai Negara). Bandung: Refika Aditama, 2016.

[13] Muladi ; Barda Nawawi Arief, Pembaharuan Hukum Pidana. Bandung: Alumni, 2007.

[14] B. N. Arief, Sari Kuliah Perbandingan Hukum Pidana. Jakarta: Raja Grafindo Persada, 2002.

[15] H. Hatrik, Asas Pertanggungjawaban Korporasi dalam Hukum Pidana (Strict Liability dan Vicarious Liability). Jakarta: Raja Grafindo Persada, 1996.

[16] N. S. P. Jaya, Hukum Pidana Khusus. Semarang: Badan Penerbit Undip, 2016.

[17] S. R. Sjahdeini, "Pemidanaan Korporasi," Kompas 3 Agustus, p. 6, 2017.

[18] Din M..[et. al.], "Pertanggungjawaban Partai Terhadap Calon Anggota Legislatif yang Melakukan Tindak Pidana," J. Penelit. Huk. Jure, vol. 16, no. 1, pp. 27-28, 2016.

[19] A. Mutasowifin, "Korupsi Korporasi dan Korupsi Partai Politik," Kompas 2 Agustus 2017, p. 7, 2017. 